\title{
CHANGES IN THE HEAD OF THE FEMUR IN CHILDREN SUFFERING FROM GAUCHER'S DISEASE
}

\author{
R. McL. Todd and S. E. Keidan, Liverpool, England \\ From the Department of Child Health, Universily of Liverpool
}

In 1882 Phillipe Gaucher, in his thesis for M.D. of the University of Paris (" D'epithelioma primitif de la rate: hypertrophie idiopathique de la rate sans leucemie"), described a new type of splenic tumour which he thought was an epithelioma; and in 1904 Brill and his collaborators described similar cases which at autopsy showed collections of cells (Gaucher cells) in the bone marrow. Junghagen, in 1926, made the first detailed report on the radiographic changes of bone in a three-year-old girl with Gaucher's disease. The extent of infiltration of bone with Gaucher cells, which contain the lipoid kerasin, determines the particular radiological findings, which in some cases are extensive. Pick (1933) suggested that the predominantly osseous form of Gaucher's disease was usually familial.

In Gaucher's disease the cells infiltrate the liver and spleen, giving rise to the characteristic hepato-splenomegaly; haemorrhages are also frequent because of the infiltration of the bone marrow which leads to thrombocytopenia and leucopenia. Radiological changes are most commonly observed at the lower end of the femur, giving rise to the "Erlenmeyer flask" appearance with expansion of the bone, destruction of the spongiosa and pressure atrophy of the cortex. Later, sclerosis of the shaft of the femur may occur. Probably second in order of frequency are the radiological changes found at the upper end of the femur, and Table I gives details of such changes in seventeen recorded cases. Our two patients also showed similar changes.

\section{CASE REPORTS}

Case 1-This was an illegitimate girl first seen in March 1948, when she was five years old. There was a history of severe constipation from birth and failure to grow. On examination she was a pale, thin child with a distended abdomen caused by a spleen which extended from the costal margin to the pelvic brim. The skull was microcephalic and there was a flexion deformity of all the terminal phalanges. A splenic puncture was performed and typical Gaucher cells were seen when the aspirated material was examined. The blood Wassermann was strongly positive, but the Wassermann reaction of the cerebrospinal fluid was negative; the mother's Wassermann reaction was negative and no history of anti-syphilitic treatment was obtained from her. Injections of "bisoxyl " and penicillin were advised for the child, and after five months' treatment the blood Wassermann reaction became negative. Splenectomy was undertaken and the spleen weighed 1,200 grammes. She was seen subsequently on several occasions in the out-patient department and her condition improved until ten months after operation, when she complained of pain in the left thigh. On clinical examination she walked with a limp, there was no muscle wasting but abduction and medial rotation of the left hip joint caused pain. Radiographs (Fig. 2) showed blurring of the upper epiphysial line of the left femur, with osteoporosis of the medial side of the head and of a circumscribed area of the neck. The pain was quickly relieved by a short period of rest and there were no further symptoms until three months later, when the pain and limp returned. In December 1949 radiological changes suggestive of Perthes' disease of the left femur (Fig. 3) were present. She was readmitted to hospital and weight-traction was applied for one month. After this she spent a period of two months on an abduction frame until a patten-top caliper was fitted and she was then seen as an out-patient. Serial radiographs are reproduced (Figs. 1 to 5) and show that the changes in the femoral head were progressive and without evidence of regeneration.

Case 2-This boy first attended hospital at the age of three years and was operated upon for a small umbilical hernia and a right-sided hydrocele. He was readmitted eighteen months later, when his spleen was enlarged to just below the umbilicus. Splenectomy was performed and the 


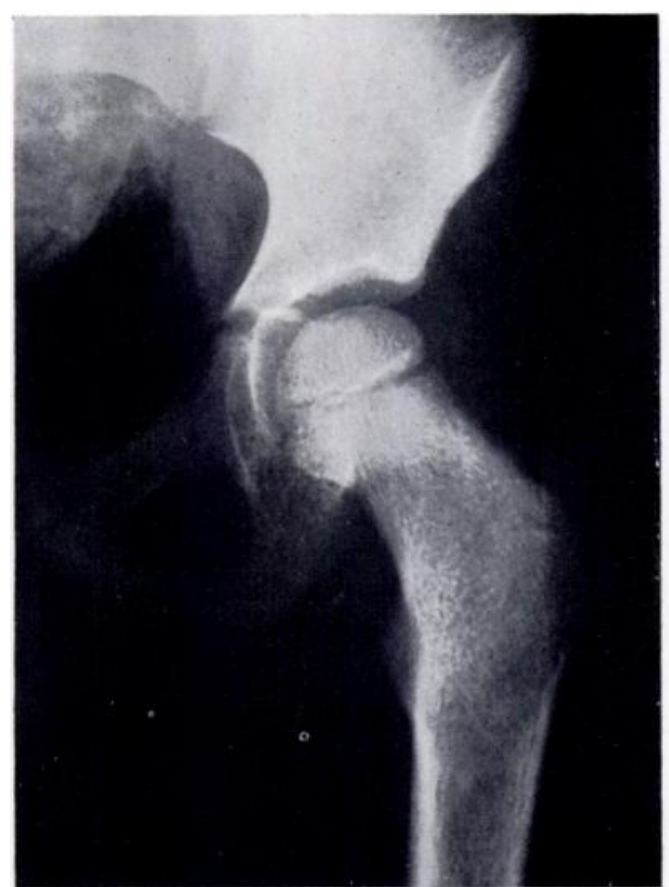

FIG. 1

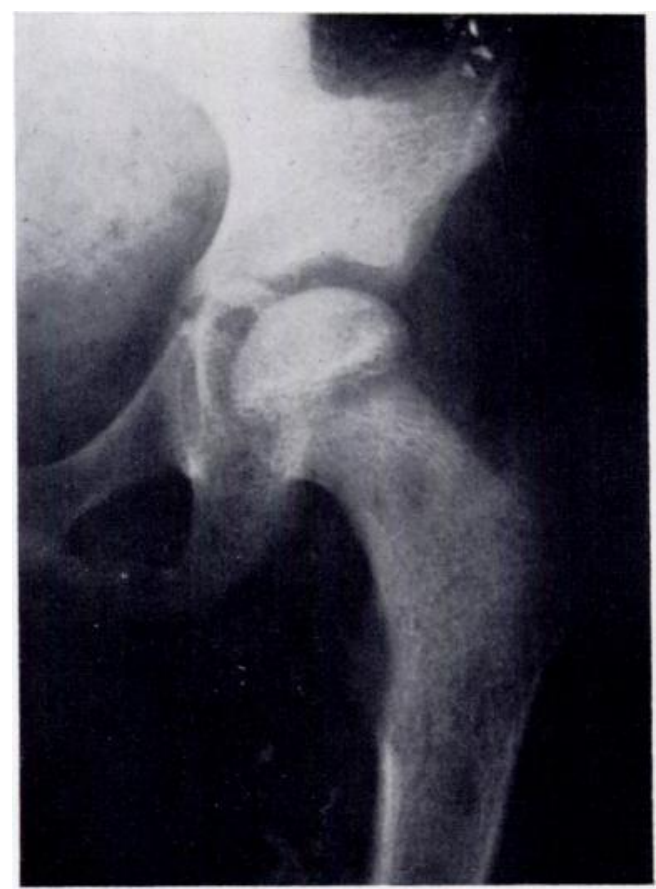

FIG. 2

Case 1. Figure 1-At first examination. No bony changes shown in hip joints. Figure 2-Eighteen months later. Blurring of the upper epiphysial line of left femur, with osteoporosis of the inner side of the head and of a circumscribed area of the neck. (Opacities over both iliac crests due to intramuscular injections of bismuth.)

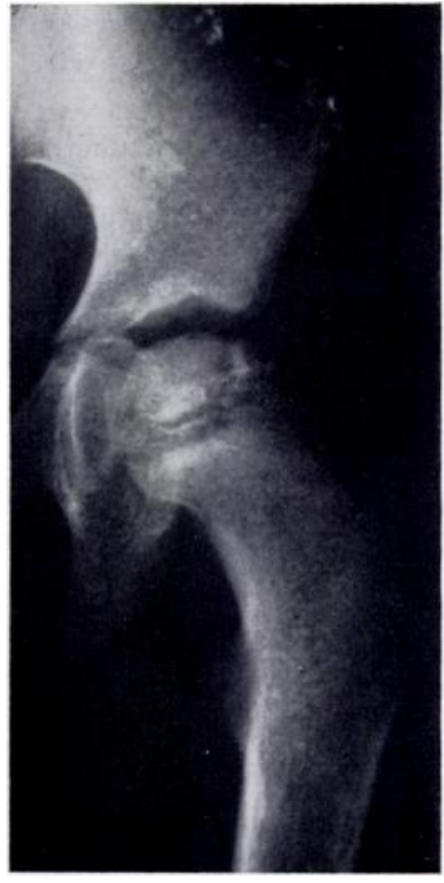

Fig. 3

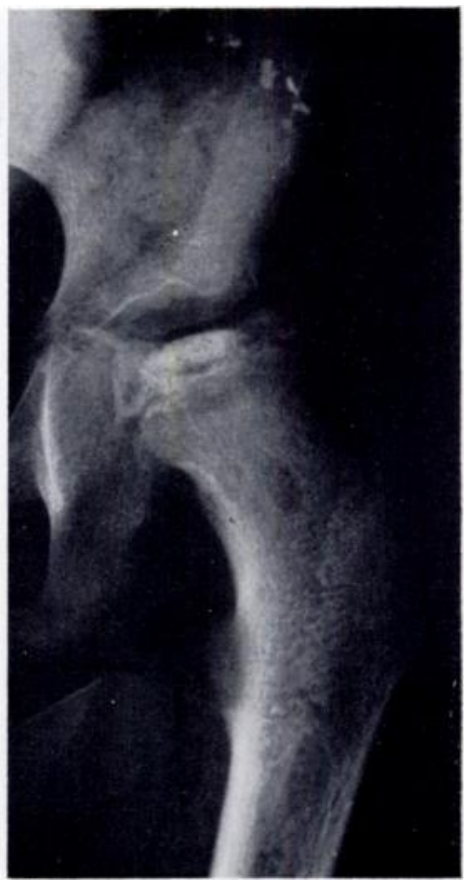

FIG. 4

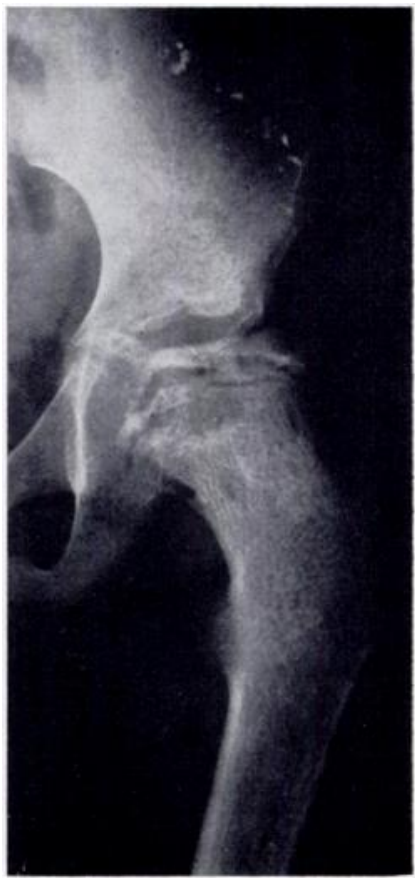

Fig. 5

Case 1. Figure 3-Twenty months after first examination. Fragmentation of head of left femur. Figure 4Three months later. Collapse of head of left femur. Two further osteoporotic areas present in neck of left femur. Figure 5-Eight months later. Marked flattening of head of left femur, with translucent areas. 


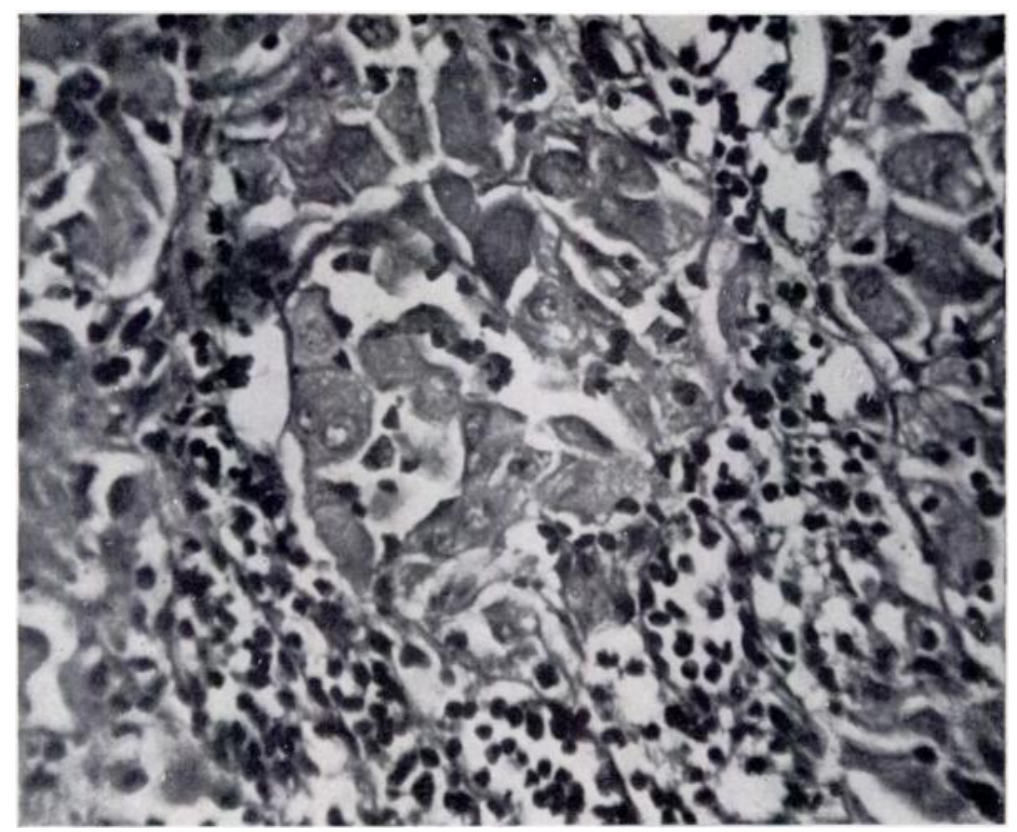

Fig. 6

Case 2-Section of spleen, removed at the age of four and a half years, showing typical Gaucher cells $(\times 360)$.

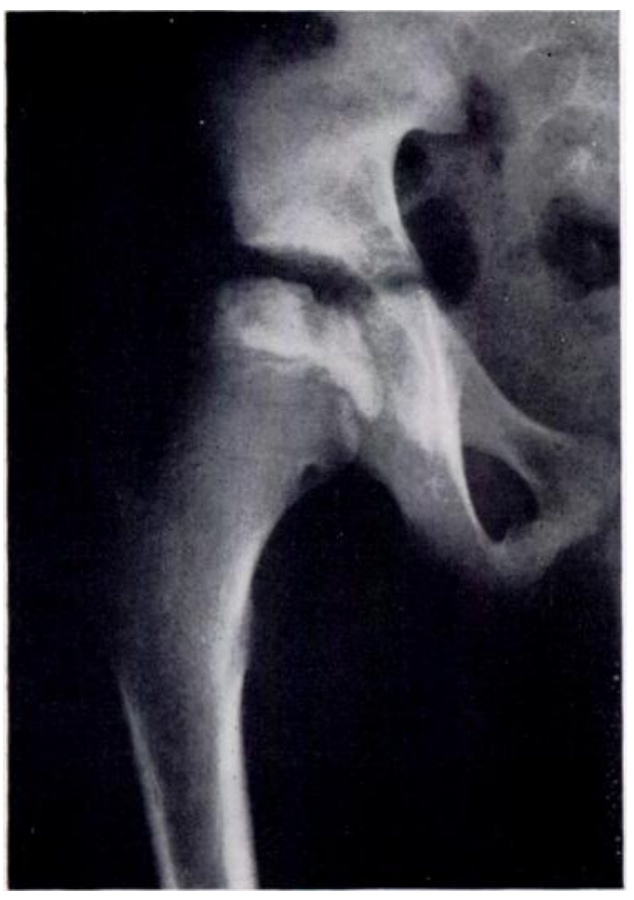

FIG. 7

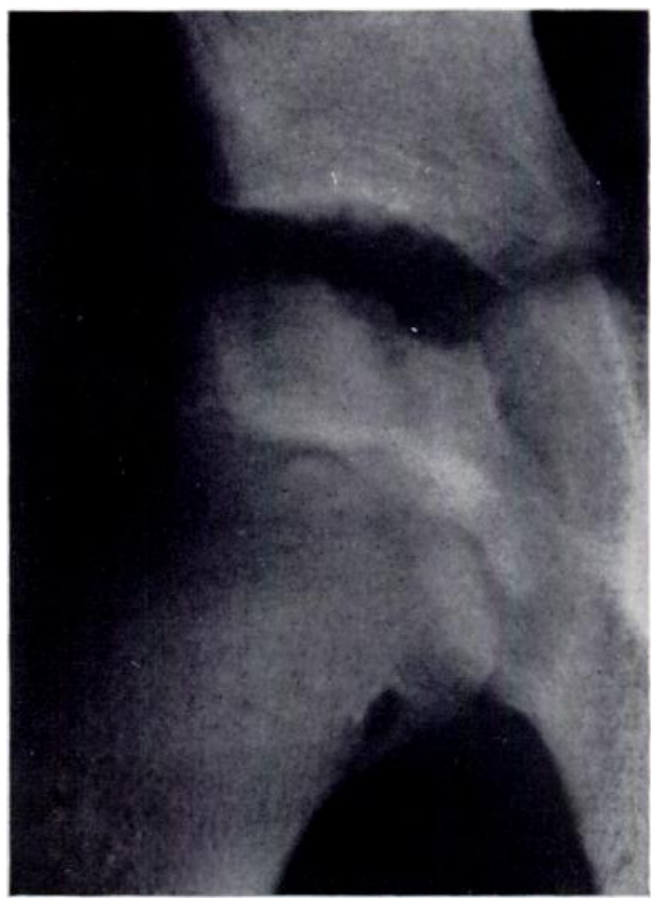

Fig. 8

Case 2. Figure 7-Right hip at the age of nine and a half years, showing irregular sclerosis with some flattening of the femoral epiphysis. The femoral neck is widened and there is a circumscribed area of osteoporosis with some surrounding sclerosis on the medial side of the neck. Figure 8-Enlarged radiograph of the femoral neck showing the same changes as in Figure 7 and, in addition, irregularity of the acetabular margin and widening of the joint space. 
spleen, which weighed 500 grammes, contained typical Gaucher cells (Fig. 6). Subsequent history was uneventful until he was readmitted to hospital at the age of nine and a half years with severe pain in the right thigh for one day, following a sore throat one week before; he was referred as a suspected case of osteomyelitis. On examination he was a pale, thin boy, with the right leg flexed at the hip and knee, and limitation of all movements of the right hip joint because of muscle spasm. A non-tender bony swelling at the lower end of the right femur was noted. Radiographic changes were present at both ends of the right femur; the changes at the upper end are reproduced (Figs. 7 and 8 ).

Sternal puncture was performed and typical Gaucher cells were found. Treatment of the hip lesion consisted of fitting a Patten-top caliper. While in hospital his tonsils were removed and typical Gaucher cells were seen on microscopical examination. He has been seen at intervals of six weeks since discharge from hospital, and the radiological appearances of the right femur are unchanged.

\section{DISGUSSION}

The radiological changes in the femoral head in these two patients resemble those encountered in Legg-Calvé-Perthes' disease. The nature of this condition has been investigated by many workers, and Brailsford (1948) enumerates eleven theories of causation, including trauma, infections, endocrine disorders, vascular causes and congenital lesions. He considers that the disease is "the reaction associated with hyperaemia and decalcification which is produced in the living bone by adjacent avascular bone." This avascular fragment is gradually absorbed as a result of infiltration by blood vessels, and eventually new bone is deposited. Many factors may be responsible for the initial disturbance of blood supply to the avascular fragment of bone, and in many cases trauma appears to be a contributory factor.

In Gaucher's disease, cells 20 to $80 \mu$ in diameter provide the characteristic microscopical feature, and they are found in many organs, including the bone marrow. Destruction of bone may result either from multiplication of Gaucher cells with subsequent pressure atrophy of bone, or from interference with blood supply by embolism or thrombosis.

Biopsy of the femoral head in Perthes' disease has been undertaken infrequently, but Cushing and Stout (1926) reported the pathological findings in a woman of thirty-three years with "Perthes' syndrome" due to Gaucher's disease. The head and neck of the patient's right femur were removed together with six sequestra from the acetabulum. On macroscopical examination the bone was soft, the marrow spaces were enlarged and the marrow had a pale pink tinge. Very little articular tissue remained on the head of the femur and the cartilage was patchy and of unequal thickness. Microscopically Gaucher cells were present within the marrow cavity and the authors concluded that the changes encountered resulted from multiplication of these Gaucher cells, followed by gradual disintegration of the joint.

Melamed and Chester (1938) described the post-mortem appearances in a man of twentysix years with Gaucher's disease showing radiological flattening of the head of the left femur. The lower proximal part of the articular surface was completely destroyed and the cartilage was absent. There was an area of softening in the head of the femur, filled with soft, greyishpink tissue, and several nodules of friable, yellowish tissue were also present which completely replaced the normal structure. Reiss and Kato (1932) considered that pressure on surrounding tissues by accumulation of Gaucher cells causes necrosis of the spongiosa leading to rarefaction of the cortex. When necrosis occurs at the epiphysis pathological fractures may occur, and if the adjoining joint surfaces are invaded, chronic arthritis ensues.

When Gaucher cells infiltrate the shaft of a bone, radio-translucent areas result, and although similar areas occur in the neck of the femur, the head usually shows an increased density. This appearance cannot be explained by multiplication of Gaucher cells in the bone marrow, but similar changes occur in diseases which interfere with the arterial supply to the bone and produce aseptic necrosis. Pick (1925) found Gaucher cells in the adventitia of small arterioles, and Graham and Blacklock (1927) noted masses of Gaucher cells in the lumina of branches of the splenic vein, as well as small nests of Gaucher cells clustered around very 
fine capillary vessels in the liver. It seems reasonable to postulate that similar involvement of the arterioles supplying the femoral head may occur and give rise to aseptic necrosis. Arkin and Schein (1948) consider that the clinical and radiological features of Gaucher's disease involving the femoral head are most satisfactorily explained by a vascular cause producing aseptic necrosis of bone. Furthermore, similar changes at the femoral head have been reported by Wintrobe (1946) in leukaemia. In the two cases here reported biopsy of

TABLE I

Seventeen Cases of Gaucher's Disease with Hip Changes in Children

REPORTED IN THE LITERATURE

\begin{tabular}{|c|c|c|c|c|}
\hline Author & Year & $\begin{array}{l}\text { Age of } \\
\text { child } \\
\text { (years) }\end{array}$ & Sex & Author's description of hip changes \\
\hline JUNGHAGEN & 1926 & 4 & $\mathrm{~F}$ & $\begin{array}{l}\text { Left hip- Epiphysis of left femoral head partly disappeared } \\
\text { leaving a larger lateral fragment and a conglomera- } \\
\text { tion of smaller barley-like fragments bordering the } \\
\text { outer edge. Compression of epiphysial centre }\end{array}$ \\
\hline LINDAU & 1928 & 3 & $\mathrm{~F}$ & $\begin{array}{l}\text { Left hip- ? T.B. Decalcification and pronounced spottiness } \\
\text { owing to round or oblong structural defects of } \\
\text { different size in spongy bone }\end{array}$ \\
\hline $\begin{array}{l}\text { WELT, ROSENTHAL, } \\
\text { OPPENHEIMER }\end{array}$ & 1929 & 8 & F & Both hips-Mottled appearance of head and neck \\
\hline Reiss, Kato & 1932 & 5 & $\mathrm{~F}$ & $\begin{array}{l}\text { Both hips-Femoral necks markedly sclerosed. Deformed } \\
\text { appearance of head resembling Perthes' disease. } \\
\text { Pathological fracture of neck on right side }\end{array}$ \\
\hline & & 5 & $M$ & $\begin{array}{c}\text { Both hips-Epiphyses showed gross irregularity of epiphysial } \\
\text { lines associated with coxa vara }\end{array}$ \\
\hline DE LANGE & 1938 & $\begin{array}{l}8 \\
7\end{array}$ & $\begin{array}{l}\mathrm{F} \\
\mathrm{F}\end{array}$ & $\begin{array}{l}\text { Left hip- Fracture of neck with sclerosis of head } \\
\text { Left hip- Destruction of head }\end{array}$ \\
\hline Pachman & 1938 & 9 & F & $\begin{array}{l}\text { Both hips-Diffuse decalcification with small areas of destruc } \\
\text { tion in femoral necks } \\
\text { Right hip- Acetabulum irregular with large areas of destruc- } \\
\text { tion especially of ilium. Porosis and angulation } \\
\text { of femoral head }\end{array}$ \\
\hline THANNHAUSER & 1940 & 7 & $M$ & $\begin{array}{c}\text { Both hips-Complete flattening of left femoral head. Perthes'- } \\
\text { like changes in right femoral head }\end{array}$ \\
\hline Perlman & 1940 & 6 & M & $\begin{array}{l}\text { Right hip- Coxa vara, and "osteomyelitis" of neck: irregular } \\
\text { density and rarefied areas }\end{array}$ \\
\hline SCHEIN, ARKIN & 1942 & $\begin{array}{r}10 \\
10 \\
5 \\
14\end{array}$ & $\begin{array}{l}\mathrm{F} \\
\mathrm{F} \\
\mathrm{M} \\
\mathrm{F}\end{array}$ & $\begin{array}{l}\text { Left hip- Perthes'-like changes } \\
\text { Left hip- Perthes'-like changes } \\
\text { Right hip-Pathological infraction with coxa vara } \\
\text { Both hips-Mushrooming of femoral heads with coxa vara }\end{array}$ \\
\hline $\begin{array}{l}\text { ARKIN, SCHEIN } \\
\text { (also MELAMED, } \\
\text { CHESTER, 1938) }\end{array}$ & 1948 & 12 & $\mathbf{M}$ & Left hip- Perthes'-like changes \\
\hline DrazNIN, Singer & 1948 & 10 & $\mathrm{~F}$ & Both hips-Perthes'-like changes \\
\hline
\end{tabular}

bone has not been undertaken. However, the spleen of each patient has been examined microscopically but we have been unable to demonstrate any vessels directly infiltrated by Gaucher cells.

At the present time no effective therapy is available for the cure of Gaucher's disease, but splenectomy is frequently undertaken for relief of symptoms. This operation is usually advised either to relieve abdominal pain and discomfort, or to prevent haemorrhages and 
the development of anaemia, which commonly occurs. There is general agreement that pain is relieved, anaemia is improved and haemorrhages cease after the operation, but some writers suggest that the development of bone changes may be accelerated by splenectomy.

The radiological bone changes in our cases were first noted in one thirteen months and in the other five years after operation. Of the seventeen children with Gaucher's disease showing involvement of the head of the femur reported in the literature, Lindau's (1928) patient developed bone changes within four months of operation; but in others-for instance in Welt's (1929) patient-bone changes were not observed until four years after operation. In adults even longer periods have elapsed between splenectomy and subsequent bone changes.

Pick (1933) has pointed out that in some instances of this disease the osseous changes predominate, and he cites a family of five brothers suffering from this condition. Furthermore, the bone changes-as in Cushing and Stout's (1926) patient-may be present before splenectomy is undertaken. Heilbron (1935) has suggested that splenectomy might prevent further bone changes, and in support of this he reports two children (subsequently described by De Lange in 1938) the younger of whom had a splenectomy and showed post-operative improvement of the skeletal changes, and the elder, who did not undergo splenectomy, developed typical bone changes. Subsequent observation of the younger child, however, showed the development of progressive bone changes. Gaucher's disease is a progressive condition and we consider it unlikely that splenectomy affects either the onset or development of bone lesions.

Local treatment of the involved hip may have a distinct bearing on prognosis of the bone lesion and Arkin and Schein (1948) describe the clincial features in a girl first seen at the age of ten years in whom, after bed rest, reconstruction of the head of the femur occurred to such an extent that the radiographic and clinical features were almost normal. These authors suggest that the advanced degenerative lesions of the hip occasionally seen in adult patients are likely to be due to lack of protection from weight-bearing in childhood when the hip is more pliable. The improvement would support the hypothesis that the changes are due to an aseptic necrosis, unless the Perthes' disease in this case was coincidental, and not due to Gaucher's disease.

The blood Wassermann reaction in Case 1 was strongly positive on several occasions, but no clinical signs of syphilis were present. The cerebrospinal fluid was normal, including negative Wassermann reaction. The Wassermann reaction of the child's mother was negative and she denied receiving anti-syphilitic treatment. The child was illegitimate and as the father's identity was unknown his blood Wassermann reaction could not be determined. In the cases of Gaucher's disease reported in the literature none have had a positive Wassermann reaction, and the standard text-books state that in Gaucher's disease the blood Wassermann reaction is negative.

Kolmer (1949) has reviewed the diseases, other than syphilis, in which the blood Wassermann reaction is positive. In addition to diseases usually found in tropical countries, such as malaria, leprosy, filariasis and leishmaniasis, the blood Wassermann reaction has occasionally been reported positive in viral pneumonias, vaccinia, infectious mononucleosis, lupus erythematosus and subacute bacterial endocarditis. In our patient no other disease was present, and technical errors in the carrying out of the test were unlikely as the result was strongly positive on several occasions. Stokes et al. (1946) performed routine Wassermann reaction on blood obtained from 210,261 blood donors and found a positive reaction in 489 $(0.23$ per cent). Nearly half of these 489 cases were finally adjudged to be syphilitic, but no cause could be found in the remainder. Furthermore, they found that the non-specific reactions were usually of low titre but occasionally a strongly positive reaction was obtained. In our patient, a diagnosis of congenital syphilis was made, and after five months of anti-syphilitic treatment the blood Wassermann reaction became negative. The bone changes in this girl were not typical of syphilis and it is considered unlikely that syphilis played any part in the 
changes present in the femoral head, because they developed fourteen months after antisyphilitic treatment had been completed and at a time when the Wassermann reaction had become negative.

\section{SUMMARY}

1. Two children suffering from Gaucher's disease, who developed changes in the femoral head typical of Perthes' disease, are reported. Similar changes have been recorded in the literature in seventeen children under the age of fifteen years.

2. The possible factors giving rise to the bone changes are discussed and it is considered that they result from aseptic necrosis. Splenectomy does not appear to hasten the development of bone changes in this disease.

3. In one of the patients, the blood Wassermann reaction was positive, but syphilis was not thought to play any part in the production of the bone changes.

\section{REFERENCES}

Arkin, A. M., and Schein, A. J. (1948): Aseptic Necrosis in Gaucher's Disease. Journal of Bone and Joint Surgery, 30-A, 631

Brailsford, J. F. (1948): The Radiology of Bones and Joints. Fourth edition. London: J. \& A. Churchill Ltd.

Brill, N. E., Mandlebaum, F. S., and Libman, E. (1905) : Primary Splenomegaly-Gaucher type. American Journal of Medical Sciences, N.S., 129, 491.

Cushing, E. H., and Stout, A. P. (1926): Gaucher's Disease: with report of a case showing Bone Disintegration and Joint Involvement. Archives of Surgery, 12, 539.

De LANGE, C. (1938): Ueber Zeitfolge des Entstehens und über Heilungstendenz der Skelettveränderungen beim Morbus Gaucher sowie über das Erscheinen der typischen Pigmentationen. Annales Paediatrici, $152,87$.

Drat.Nin, S. Z., and Singer, K. (1948): Legg-Perthes' Disease: a Syndrome of Many Etiologies ? with Clinical and Roentgenographic Findings in a case of Gaucher's Disease. American Journal of Roentgenology, 60, 490.

Graham, S., and Blacklock, J. W. S. (1927): Gaucher's Disease: a Clinical and Pathological Study. Archives of Disease in Childhood, 2, 267.

Heilbron, L. G. (1935): Het beloop van de skeletafwijking bij de zieke van Gaucher. Nederlandsch Tijdschrift voor Geneeskunde, 79, 823.

JUnghaGEN, S. (1926): Röntgenologische Skelettveränderungen bei Morbus Gaucher. Acta Radiologica, $5,506$.

Kolmer, J. A. (1949): Clinical Diagnosis by Laboratory Examinations. Second edition. New York: Appleton-Century-Crofts Inc.

Lindau, A. (1928): A Case of Gaucher's Disease. Acta Pathologica et Microbiologica Scandinavica, 5, supplement, p. 22.

Melamed, S., and Chester, W. (1938): Osseous Form of Gaucher's Disease. Archives of Internal Medicine, 61, 798.

Pachman, D. J. (1938): Chronic Gaucher's Disease. American Journal of Diseases of Children, 56, 248.

Perlman, H. H. (1940): Chronic Gaucher's Disease. Journal of Pediatrics, 16, 191.

Pick, L. (1925): Zur Histiogenese der Gaucherzellen in der Milz. Virchow's Archiv für pathologische Anatomie und Physiologie, 254, 782.

Pick, L. (1933): 'A Classification of the Diseases of Lipoid Metabolism and Gaucher's Disease. American Journal of the Medical Sciences, 185, 453.

Reiss, O., and Kato, K. (1932): Gaucher's Disease: a Clinical Study, with special reference to Roentgenography of Bones. American Journal of Diseases of Children, 43, 365.

Schein, A. J., and ARKin, A. M. (1942): Hip-joint Involvement in Gaucher's Disease. Journal of Bone and Joint Surgery, 24, 396.

Stokes, J. H., Boerner, F., Hitchens, A. P., and Nemser, S. (1946): Non-specific Reactions in Routine Blood Testing for Syphilis. Journal of the American Medical Association, 130, 57.

Thannhauser, S. J. (1940): Lipidoses: Diseases of the Cellular Lipid Metabolism. New York: Oxford University Press.

Welt, S., Rosenthal, N., and Oppenheimer, B. S. (1929): Gaucher's Splenomegaly with especial reference to Skeletal Changes. Journal of the American Medical Association, 92, 637.

Wintrobe, M. M. (1946): Clinical Hematology. Second edition. London: Henry Kimpton.

vol. 34 B. No. 3, AUgust 1952 